Research Article

Paula Catarino*

\title{
The Articulation of Didactic Engineering with the Didactic Situations Theory: Examples of Applications to the Study of Integer Sequences
}

https://doi.org/10.1515/edu-2020-0127

received July 27, 2020; accepted October 19, 2020.

\begin{abstract}
According to the guidelines of the Didactic Engineering as a research methodology and in complementarity with the Didactic Situations Theory, we will show how Didactic Engineering and the Didactic Situations Theory can be articulated to study integer sequences. We will present two examples of applications of this articulation between Didactic Engineering and the Didactic Situations Theory to the study of numerical sequences and it is our intention to describe the main elements of two initial stages of Didactic Engineering, namely, Preliminary Analysis and Design and a priori Analysis. We will highlight the conception of didactic situations and the possible behaviors and resolution of the students before the problem situations, organized for purposes of experimentation.
\end{abstract}

Keywords: Didactic Engineering; Didactic Situations Theory; Integer sequences.

\section{Introduction}

The work presented here aims to reflect on some models of generalization and extension of numerical sequences. Thus, in line with the guidelines of Didactic Engineering as a research methodology and in complementarity with the Didactic Situations Theory, which allows a thorough analysis of the phenomena related to teaching and learning the topic of sequences, we will describe the main elements that constitute the two initial stages of a classic Didactic Engineering (Didactic Engineering of 1st generation), namely, the Preliminary Analysis stage and

*Corresponding author: Paula Catarino, Department of Mathematics, University of Trás-os-Montes e Alto Douro, 5001-801 Vila Real, Portugal, E-mail: pcatarin@utad.pt the Design and a priori Analysis stage, emphasizing the design of "Didactic situations" and the possible behaviors and resolutions of the students before some problem situations, organized for the purpose of experimentation.

This work will show some applications of these stages of Didactic Engineering and the stages of Didactic Situations Theory to the cases of some well-known numerical sequences.

Didactic Engineering as a research methodology based on design, has been applied in several fields of education. The work in the field of teaching of exact sciences (Berenguer, 2010), teaching of science (Guimarães, Barlette, \& Guadagnini, 2015), music education (AngelAlvarado, Wilhelmi, \& Belletich, 2017) and teaching of physics (Lima, \& Ferreira, 2020), are some examples.

Many other works related to Didactic Engineering can be found in the literature, such as those by Godino, Rivas, Arteaga, Lasa and Wilhelmi (2014), where the authors analyzed the possible connections between Didactic Engineering and the approach to research in the teaching of Mathematics - "Design-based research" (DBR) - having concluded that Didactic Engineering can be seen as a particular case of DBR, linked to the Didactic Situations Theory, or that DBR is a generalization of Didactic Engineering that uses other theoretical frameworks such as foundations for planning teaching experiences.

In Brazil, several authors studied Didactic Engineering and its applications, for example, the works of Machado (2002), Almouloud (2007), Alves (2017, 2018), Souza and Alves (2018), Alves and Alves Dias (2017) and Alves and Catarino (2017, 2018, 2019).

In the next sections, what is essential in relation to Didactic Engineering and Didactic Situations Theory will be presented; the reference to Didactic Transposition, which has a strong connection and weight in preparing mathematics for our students will not be forgotten; contributions from different authors on these themes/ topics will be mentioned; a connection will be made between these methodological instruments. 
To relate these two approaches, we will follow the path of the studies mentioned, with the appropriate adjustments, applying these theories to the study of Fibonacci and Jacobsthal sequences.

\section{2 didactic situations theory}

According to González-Martin, Bloch, Durand-Guerrier and Maschietto (2014), the Didactic Situations Theory dates back to the late 1960s when Brousseau (2008) began to think, not only about the conditions that would ensure a rigorous construction of mathematical knowledge based on a model of teaching and learning systems, but also the determination of the conditions of scientific observation of didactic activities. According to Warfield (2006), Brousseau (1997) reflected on these questions/ reflections ( 1 - what conditions guaranteed a rigorous construction of mathematical knowledge based on a model of teaching and learning systems; 2 - determining the conditions for scientific observation of teaching activities), and formed the opinion that psychology should not be used solely and exclusively to answer them. At the time, he pointed out three main reasons that led him to take this position, namely: the fact that Piaget's work focuses on each child in an individual way; the fact that constructivist approaches are insufficient to model the learning processes of mathematics in a satisfactory way - that is, their social and cultural dimensions are not sufficiently taken into account (Artigue, 1999, p. 1378); and the fact that these approaches do not fully articulate the relationship between the didactic activity in question and the mathematical content to be studied (Artigue, 2000).

It was then that the concept of "situation" emerged, which was seen as an ideal model of the system of relationships that involves students, teacher and "mathematical environment". Student learning was then seen as a result of interactions that occur in this system and depends on its characteristics.

Various types of situations can occur when this model is applied. Thus, the theory is structured around the notions of "Didactic situations" (which occur when there is an intention of learning, implicit or explicit) and "Adidactic situations" (didactic situations, in which the student must perceive the characteristics and patterns that will help him to understand a new knowledge, where the teacher acts only as a mediator/observer) and includes a set of relevant concepts for teaching and learning in mathematics classrooms.

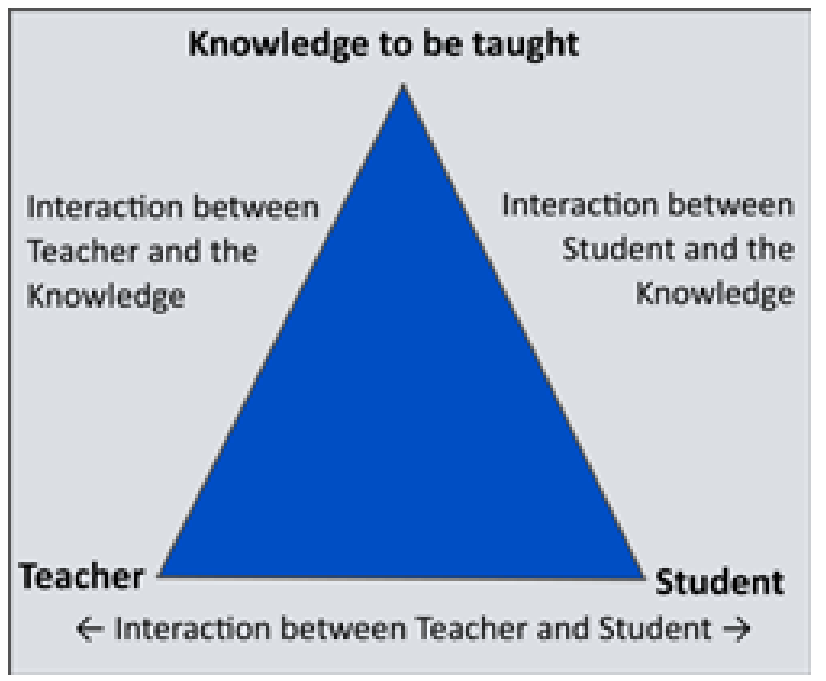

Figure 1: The didactic triangle of Brousseau. ${ }^{1}$

A "didactic situation" is formed by the several pedagogical relationships established between teacher, students, and knowledge, in order to develop activities aimed at teaching and learning specific content.

Brousseau (1996, 1996a) proposes the following didactic triangle (Figure 1), composed of three elements the student, the teacher, and the knowledge to be taught.

These three elements are also part of a dynamic and complex relationship - the didactic relationship where the interactions between teacher and students are considered, mediated by the knowledge that determines how these relationships will develop.

\subsection{Didactic situations}

Didactic situationsarecategorizedintoaction, formulation, validation, and institutionalization situations.

\section{Action situation}

The "didactic situations" of action are those in which the student, who is actively engaged in the search for a solution to a certain problem, performs certain more immediate actions, which result in the production of knowledge of a more operational nature.

1 Image retrieved from https://www.google.com/search?q=The+di dactic+triangle+of +Brousseau\&rlz=1C1GCEA_enPT876PT876\&sxsrf $=$ ALeKk03k8504pLzbB-CHAEykDXpxxiAX_A:1595092909646\&sourc $\mathrm{e}=\operatorname{lnm} s \&$ tbm $=$ isch\&sa $=$ X\&ved $=2$ ahUKEwiBjY2SqNfqAhV1DWMBHdiqDmcQ_AUoAXoECAsQAw\&biw=1600\&bih=789\#imgrc=0h-khUaUPqvnpM in 2020-07-18 
Formulation situation

The "didactic situations" of formulation are those in which the student already uses, in solving the studied problem, some explicit theoretical models or schemes, in addition to showing an evident working with theoretical information in a much more elaborated way.

\section{Validation situation -}

The "didactic situations" of validation are those in which the student already uses mechanisms of proof and where knowledge is used for this purpose.

\section{Institutionalization situation -}

The "didactic situations" of institutionalization are those where the aim is to establish the character of objectivity and universality of knowledge.

\subsection{Adidactic situations}

Adidactic situations are also divided into "adidactic situations" of action, formulation, validation, and institutionalization.

\section{Action situation -}

The "adidactic situations" of action are those in which the student attempts to use previous knowledge to try to solve the problem.

\section{Formulation situation -}

The "adidactic situations" of formulation are those in which the student attempts to formulate general conjectures about the type of problem. It is the phase in which the student begins to generalize and to be able to distinguish, whether they are true or not.

\section{Validation situation -}

The "adidactic situations" of validation are those in which the student tries to explain some type of proof for the conjectures formulated by himself.

\section{Institutionalization situation -}

The "adidactic situations" of institutionalization are those in which the teacher exposes the relevant knowledge raised by the students during the validation and its connection with the other knowledge and knowledge already established.

To recap, the stages of development of the Didactic Situations Theory are: action, formulation, validation and institutionalization. In action, students analyze the context and make decisions, which includes the development of strategies. In the formulation, the student regains established knowledge and involves other subjects who cooperate with the activity. The validation is characterized by the support of the students on the set of data obtained during the experimentation and observations of the teacher. In institutionalization, the teacher exposes what was most relevant during the validation.

According to Artigue (1999), for the construction of situations that optimize the relations between the mathematical activity of the teacher and that of the students in order to maximize the student's responsibility in this activity, Didactic Situations Theory develops a set of conceptual tools that are going to be useful. One of these conceptual tools is the notion of didactic contract owed to Brousseau (1996a) and which is nothing more than an implicit set of expectations that the teacher and student have of each other regarding mathematical knowledge and the distribution of responsibilities during the teaching and learning processes. The didactic contract regulates the intentions of the student and the teacher regarding the "Didactic situation".

A concept that is also important in this theory is the concept of "milieu", which is everything that interacts with the student in an antagonistic way, that is, in order to challenge the student to find answers to problem situations. According to Pomer (2013), the "milieu" can include, among other resources, problem situations, games, the knowledge of colleagues and of the teacher.

\subsection{Didactic Transposition}

According to Menezes and Santos (2001), Didactic Transposition had its genesis in 1975 by sociologist Michel Verret and was theorized by Yves Chevallard in the book "La Transposition Didatique", where he shows the transpositions that knowledge undergoes when it passes from the scientific field to school.

In the opinion of Polidoro and Stigar (2010), the definition adopted by Chevallard (1991) for Didactic Transposition is that of "a process in which a content of knowledge that was designated as knowing how to teach undergoes, from then on, a set of adaptive transformations that go make it fit to occupy a place among teaching objects” (p. 2).

There are authors (Chevallard (1991); Melzer (2012); Melzer, Simões Neto, \& Silva (2016)) who argue that the transformation of scientific knowledge into school knowledge takes place in two stages: an external 
transposition, in terms of the formal curriculum and textbooks, and another internal, during the curriculum in action, inside or during the classroom.

Pereira, Paiva and Freitas (2018) are of the opinion that this transformation undergoes even more stages. The ideas that Pereira et al. (2018) adopted to clarify the definition of Didactic Transposition are interesting. These authors suggest that the Didactic Transposition processes are: the epistemology of the didactic regime of knowledge (mathematical notions); the noosphere (where the interaction between the education system (teacher-student-knowledge) and society occurs), the didactic creations ("content" created motivated by the needs of teaching to act as resources for other learning), the epistemological surveillance (surveillance exercised so that there are no conceptual distortions in the object taught that can be caused by the process of adapting scientific knowledge to the teachable), the desyncretization of knowledge (denomination adopted by Verret (1975) associated with the textual construction of a certain content or mathematical theory that concerns the separation and organization of the theory in areas), the depersonalization of knowledge (associated with the textual construction of a given content or mathematical theory that makes a given knowledge unrelated to its author), the programmability of knowledge (consists of establishing a programming according to a progressive and rational didactic sequence), the advertising of knowledge (explicit definition of the knowledge that should be taught), the social control of learning (which is expressed in the assessment practices for official certifications), the old/new dialectic (the construction of mathematical knowledge is motivated by a problem that must be addressed by old and new mathematical knowledge), the external obsolescence (a process that occurs in relation to society, that is, it is a historical and cultural erosion of knowledge, which is no longer useful for the economy of the education system) and internal (it refers to school knowledge in relation to the length of a teaching cycle), the chronogenesis (based on the fact that the teacher knows more mathematical content, in the different areas and their interrelations, which enables instrumentalizes him to program the teaching and learning time) and the topogenesis (it concerns the dimension and the domain of the object of knowing that the teacher holds and that the student does not yet).

In French research of didactics of mathematics, the question of preparing mathematics for students is inserted in a junction between two theoretical fields that are not independent, but still distinct: the Didactic Transposition Theory, developed since the beginning of 1980 by
Chevallard (1991, 1992), and the Didactic Situations Theory, initiated by Brousseau (1986) in the early 1970s and developed by several researchers since then.

\section{Didactic Engineering}

The notion of "Didactic Engineering" was introduced in France in the early 1980s to describe a research approach in mathematics education comparable to that of an engineer. Such comparison has to do with the fact that when executing a project, the engineer has scientific knowledge of his domain, agrees to submit the project to scientific scrutiny, but at the same time he is forced to solve more complex issues than those of the science and, he is therefore solving problems that science cannot yet take on (Artigue, 1988). In fact, according to Pomer (2013), Didactic Engineering appeared in France in the late 1960s, during the discussions developed at the Institute for Research in the Teaching of Mathematics. In the early days, this Institute aimed to develop a complement to the training of mathematics teachers and to encourage the production of materials to support the work within the classroom.

Douady (1995) refers to the fact that the French mathematician Henri Léon Lebesgue (1875 - 1941), at the beginning of the century, expressed serious concerns about the conditions of teaching and teacher training. He also mentions that program reforms were determined, pedagogical decisions were made and that under the influence of researchers from different areas: mathematics, psychology, educational sciences, and also linguistics, history, sociology, especially in France, there was a strong mobilization of changes and a replacement of paradigms in the field of mathematics teaching.

Since then, in France, in the field of research in mathematical education, Didactic Engineering has had an important impact on its development and the use of this methodological approach has led to a further development of this notion and its research practices (Margolinas \& Drijvers, 2015).

According to Tempier, (2016), Didactic Engineering is a research methodology for the design of tasks based on didactic implementations in the classroom, that is, in the design, implementation, observation and analysis of teaching sequences. Thus, Didactic Engineering is a methodology that follows the existing tradition of research in the teaching of Mathematics, giving a central role to the design of task proposals and to implementation/ experimentation them in the classroom. It is a qualitative methodology and at the beginning its main objective 
was to study problems related to the learning of specific knowledge of mathematics, such as the diagnosis of conceptions, difficulties and obstacles, the understanding of the levels of development of students' strategies, learning, the introduction and construction of specific knowledge, the training of teachers, and, among others, to explain the relationship between mathematics themes and other areas of knowledge (Pomer, 2013).

According to Lima and Ferreira (2020), Didactic Engineering has been established in two forms of applications: one as a methodological tool for qualitative research in the area of Mathematics and another with the guiding dynamics for the elaboration and analysis of didactic situations that aim to create a meaningful learning scenario in classroom expanding its applicability to different teaching areas.

Didactic Engineering, as a methodology described by Brun (2000), comprises four stages: the first stage is that of preliminary analysis, the second stage is that of design and a priori analysis of Didactic Engineering situations, the third stage is that of experimentation and the fourth and final stage, is that of $a$ posteriori analysis and validation.

At the stage of

\section{Preliminary analysis}

not only considerations involving the more general theoretical-didactic framework are made, but also considerations about more specific knowledge involving the research theme (Pomer, 2013).

At this stage, according to Pomer (2013), a bibliographic review is made involving the conditions and contexts present at the various levels of didactic production and in the environment where the research will take place, as well as a general analysis regarding the historical-epistemological aspects of the teaching subjects to be worked on and the effects caused by them, conception, difficulties and obstacles encountered by students within this teaching context.

The stage of

\section{Design and a priori Analysis}

is guided by the definition of a few variables that supposedly interfere with teaching and learning. As a consequence of the results obtained in the previous stage, the researcher manages his choices and determines the number of didactic variables that may be relevant in his study. The a priori analysis must have a descriptive and anticipated character, the analysis being linked to the characteristics of the "Adidactic situation" developed and applied to the students. The descriptive and anticipated character are relevant within the student's role.

Considering Lima and Ferreira (2020), in the stage of

\section{Experimentation}

the application of the designed and constructed didactic sequence is experienced, in addition to being one of the moments in which the researcher collects data and eventually needs a record of these experiences, (e.g. audio, filling out observation forms, filming and other records).

This stage can consist of one or more classes/sessions. In the beginning, and in detail, the teacher should present the objectives in a clear and noticeable way.

Finally, the stage of

Post-analysis and validation

is dedicated to the treatment and analysis of the set of data obtained during the experimentation stage. For validation, a confrontation with the a priori analysis is made, allowing the interpretation of the results and under what conditions the questions raised were answered. In this stage, the hypotheses conceived in the research carried out are confirmed or not.

Some features of Didactic Engineering that we briefly highlight are then:

- This methodology is based on teaching interventions in the classroom, that is, on the design, implementation, monitoring and analysis of teaching sequences.

- The validation is essentially internal, based on the confrontation between the $a$ priori and a posteriori analyzes (there is no external validation, based on the comparison of performances in the experimental and control groups).

Godino, Batanero, Contreras, Estepa, Lacasta and Wilhelmi (2013) also point out and highlight these essential characteristics, being of the opinion that Didactic Engineering is an example of design-based research, but with some peculiarities: it is supported by a theory of explicit base of intermediate level, the Didactic Situations Theory (Brousseau 1997); epistemological issues are crucial, and the method of validation is mainly internal and carried out by confronting $a$ priori and $a$ posteriori analyzes. 


\section{The articulation of Didactic Engineering with Didactic Situations Theory in the teaching and learning of numerical sequences}

Being a teacher has several challenges, requiring permanent updating of knowledge and strategies to teach. One of the fundamental assumptions for working in the classroom is that the teacher develops and applies sequential teaching strategies, so that the student himself fits into an iterative and autonomous dynamic to develop and promote his own learning.

The preparation of mathematics for students cannot be perceived as a simple process of realizing knowledge established elsewhere, such as the simple search for a presentation of some mathematical content adapted to the students' previous knowledge and cognitive skills. It is perceived as a didactic task that requires a more global systemic analysis.

To put into practice the assumptions presented in the previous sections, we chose as a starting point to exemplify a didactic sequence involving the study of numerical sequences.

In this work, the relevance of the fundamental role of mathematical definitions is emphasized. In this sense, mathematical definitions not only assist us in building a solid and reliable ground of theoretical models linked and derived from a formal notion, but they can also provide an understanding of the generalization process of conceptual objects (Alves, 2016).

In the following subsections we present two examples of studying a numerical sequence in which this theme is applied. In many works of this kind, one of the aspects that is taken into account is the possibility of carrying out efficient didactic transpositions (Chevallard, 1991), with the aim of making necessary modifications on a specific mathematical knowledge. This is often only discussed in a restricted circle whose dissemination is done through scientific papers and specialized magazines.

We aim to highlight elements and approaches for the exploration of certain mathematical contents in the classroom that can provide an understanding of the epistemological, historical and evolutionary mathematical process, as was done by Alves (2015, 2016a, 2016b, 2016c).

We intend to emphasize elements and learning paths (Civiero \& Sant'Ana, 2013) for the exploration of certain mathematical contents in the classroom and that provide an understanding of the epistemological, historical and mathematical evolutionary process (Alves, 2015, 2016a, 2016b, 2016c).

Next, we present two examples of the application of the articulation between Didactic Engineering and Didactic Situations Theory to the study of these numerical sequences.

\subsection{Example with Fibonacci sequence}

The study presented in this subsection is included in the work of Santos and Alves (2017), where the first two stages of Didactic Engineering are described (Preliminary Analysis; Design and a priori Analysis) with the theme related to the properties of the Fibonacci sequence. We present one problem situation ("Didactic situation"), where the Didactic Situations Theory will be used to indicate possible interactions that can be explored involving the trinomial Teacher - Knowledge - Student. In this "Didactic situation", the four phases by which Didactic Situations are governed are described: Didactic situation of action; Didactic situation of formulation; Didactic validation situation; Didactic situation of institutionalization. Also, in this "Didactic situation" we will present the context, the objective of the activity and the Didactic Hypothesis.

In this study, the approach a proposal for a theoreticalconceptual description, entails the first two stages of Didactic Engineering that fits in a context of concern in providing a technical device and a set of communicable and reproducible "Didactic situations", in the classroom, involving the notion of Fibonacci sequence.

The leading question of this work was: "How to develop a study on the process of generalization of the sequence of Fibonacci promoting teaching situations involving the identification, description and operating properties of its generalized model?" In order to have conditions to answer the leading question, the following general objective was considered: to describe elements of a study concerning the models of generalization of the Fibonacci sequence that promote the identification, description and exploitation of properties related to these models. In order to achieve the overall goal, the following specific objectives were designed: 1) To analyze the historical-mathematical development epistemological analysis of the Fibonacci sequence; 2) To analyze the historical-mathematical development epistemological aspect of Binet's formula; and 3) To describe "Didactic situations" involving the generalization model of the Fibonacci sequence. 
To work these goals, we present what was done in the first two stages of Didactic Engineering.

\subsubsection{Preliminary analysis}

In this stage, the didactic and epistemological analysis of the historical-mathematical object under study - the Fibonacci sequence - was performed, characterizing the identification and description of some properties of its generalization and extension process.

A bibliographical survey was previously carried out in History of Mathematics books in order to collect the historical, epistemological, and mathematical evolution of the generalization models of the Fibonacci sequence elements.

In the didactic dimension, the approach given to the Fibonacci sequence in the History of Mathematics books was observed. In the epistemological dimension, aspects related to the historical evolution of the content were observed, as well as its relationship with other mathematical contexts. Some elementary properties of the Fibonacci sequence were studied.

\subsubsection{Design and a priori Analysis}

Contexts, objectives, and didactic hypotheses were defined. In addition, guided by the steps of the Didactic Situations Theory, the possible behaviors, and resolutions of the students of the four didactic situations (problem situations) organized with the purpose of being experienced (stage of Experimentation) were presented.

In this phase, the choices made are described, where some variables are defined, to direct the research and propose an action plan. Some variables are intended to guide research choices, while others are aimed at predicting possible behaviors and barriers for students, through "Didactic situations".

Thus, as we were interested in exploring some of the properties listed in the preliminary analysis stage, four "Didactic situations" were prepared, considering the relationships previously established. However here we present only the first Didactic situation.

\section{"Didactic situation" 1 - The Fibonacci Rabbits}

Context: the didactic situation deals with two models of generalization of the Fibonacci sequence: the modeling of the problem of immortal rabbits and the extension of the Fibonacci sequence to integer indices.
Month $1-1$ young couple

Month 2 - 1 mature couple

Month 3-1 young couple and 1 mature couple

Month 4-1 young couple and 2 mature couples

Month $5-2$ young couples and 3 mature couples

Month $6-3$ young couples and 5 mature couples

Month $7-5$ young couples and 8 mature couples

Figure 2: Scheme during the first seven months.

Objective of the activity: to present and discuss the generalization models of the Fibonacci sequence related to the problem of immortal rabbits and the extended Fibonacci sequence.

Didactic hypothesis: students must be able to establish a recursive equation from the interpretation of the rabbit problem, in addition to realizing the possibility of extending the sequence to integer indices.

This is the following problem, proposed and resolved by Leonardo de Pisa, in his book Liber Abaci, from 1202, proposed in Latin as Quot paria coniculorum in uno anno ex uno pario germinentur. In other words: one couple of newborn rabbits was put in a confined space. Determine how many pairs of rabbits there will be after one year, assuming that each month a couple of rabbits produces another couple and that a couple begins to procreate two months after birth (Hefez, 2003, p. 26 apud Santos and Alves, 2017, p. 454).

Questions were then asked about the proposed problem. We present some of them: Using the scheme (Figure 2), answer the following questions:

- What sequence would relate to the situation of the birth of rabbit pairs?

- Explain their choices, indicating a symbology convenient for the first term, for the second term, to the third term and thus successively.

- Can we establish a relationship that generalizes these results?

We describe what we do in each phase of Didactic Situations Theory.

\section{Action situation -}

From the analysis of the proposed scheme, the student should seek to establish a relationship between the period (months) and affiliations (number of couples), characterizing the following situation: in the first month, we will have only a young couple of rabbits, who have not yet reached maturity; in the second month, we will still have a single couple, this being now mature, and able to reproduce; in the third month, the mature couple from the 
previous month, reproduce and generate a young couple, obtaining in this period two couples, one young and one mature; in the fourth month, while the young couple from the previous month reaches maturity, the mature couple reproduces, obtaining three couples in this period. The student must be able to perceive this dynamic from the proposed scheme.

\section{Formulation situation -}

In this phase, the student must have understood the maturation and reproduction dynamics of the rabbit couples and that this process occurs continuously, with a defined recurrence pattern. At the end of this stage, the student should be able to express the following sequence:

$\left\{f_{n}\right\}_{n}=\{1,1,2,3,5,8,13, \ldots\}$

\section{Validation situation -}

After obtaining the sequence, the student should be encouraged to present his results in mathematical notation. The student must obtain the following relationship (Figure 3)

In the end, the student should be able to obtain a more general result that models the situation, for example, for $n$ $\geq 2, f_{n}=f_{n-1}+f_{n-2}$.

\section{Institutionalization situation -}

Upon resuming the discussions, we highlight the study carried out and the Fibonacci sequence recurrence and formalization model based on the problem of rabbits.

\subsection{Example with Jacobsthal sequence}

With this sequence we follow the same stages of Didactic Engineering and the phases of Didactic Situations Theory.

We present the Souza and Alves (2018) example, where the first two stages are described (Preliminary Analysis; Design and a priori Analysis) of Didactic Engineering with the theme related to the properties of the Jacobsthal sequence.

\subsubsection{Preliminary analysis}

In this stage, the didactic and epistemological analysis of the historical-mathematical object under study - the Jacobsthal sequence - was performed, characterizing the identification and description of some properties of its generalization and extension process. We use History of Mathematics books in order to collect the historical,

$$
\begin{aligned}
& \int n=1 \rightarrow f_{1}=1 \\
& n=2 \rightarrow f_{2}=1 \\
& n=3 \rightarrow f_{3}=2=f_{1}+f_{2} \\
& n=4 \rightarrow f_{4}=3=f_{2}+f_{3} \\
& n=5 \rightarrow f_{5}=5=f_{3}+f_{4} \\
& n=n \rightarrow f_{n}=f_{n-1}+f_{n-2}
\end{aligned}
$$

Figure 3: The relationship between the elements of the sequence $\left\{f_{n}\right\}_{n}$.

epistemological, and mathematical evolution of the generalization models of the Jacobsthal sequence and so the first stage is similar with the one we describe for previous sequence elements.

\subsubsection{Design and a priori Analysis}

We start this stage with the first problem.

Situation problem 1: We know that the Binet formula is given by

$$
J_{n}=\frac{\left(2^{n}-(-1)^{n}\right)}{3}
$$

From this relationship, show that

$$
J_{-n}=\frac{(-1)^{n+1}}{2^{n}} \cdot J_{n}
$$

In view of this problem, we will try to solve it by going through the four phases of theory of "Didactic situations". Using the phases of Didactic Situations Theory, we start with the first phase.

\section{Action situation -}

The teacher must encourage the manipulation of cases. In a preliminary way, the student can compare the relationships

$$
J_{n}=\frac{\left(2^{n}-(-1)^{n}\right)}{3}
$$


and

$$
J_{-n}=\frac{(-1)^{n+1}}{2^{n}} \cdot J_{n}
$$

seeking to understand and establish familiarities between them.

Now we have the second phase of Didactic Situation Theory to solve the first problem.

\section{Formulation situation -}

The formulation situation is marked by the existing interactions in the proposed activity. Such a situation is characterized by the exchange of knowledge between students. This transfer of information can be expressed through written or oral messages. In addition, the language used by the student at this stage can be natural language or mathematical. Thus, some cases can be proposed, namely:

$$
\begin{gathered}
J_{-1}=\frac{(-1)^{1+1}}{2^{1}} \cdot J_{1}=\frac{1}{2}, J_{-2}=\frac{(-1)^{2+1}}{2^{2}} \cdot J_{2}= \\
=-\frac{1}{4}, J_{-3}=\frac{(-1)^{3+1}}{2^{3}} \cdot J_{3}=\frac{3}{8}
\end{gathered}
$$

It is worth mentioning that the position taken by the teacher, who is the driver of the process, is important, bearing in mind that it will act as a stimulator for the cases described previously. Finally, the teacher can encourage the student to raise the following conjecture:

$$
J_{-n}=\frac{(-1)^{n+1}}{2^{n}} \cdot J_{n}
$$

Now we have the third phase of Didactic Situation Theory in order to solve the first problem.

- Validation situation -

In this phase, the student tries to convince one or more of his colleagues of the legitimacy of the assertions that are made. Thus, this type of situation is related to the rational argumentative plan and is concerned with the question of the veracity of knowledge. Thus, using the Binet formula, we have the following deduction:

$$
J_{-n}=\frac{\alpha^{-n}-\beta^{-n}}{3}=\frac{\frac{1}{\alpha^{n}}-\frac{1}{\beta^{n}}}{3}=\frac{\frac{1}{\alpha^{n}}}{3}-\frac{\frac{1}{\beta^{n}}}{3}=\frac{1}{3 \alpha^{n}}-\frac{1}{3 \beta^{n}}=
$$

$$
\begin{gathered}
=\frac{\beta^{n}-\alpha^{n}}{3 \alpha^{n} \beta^{n}}=\frac{\left(\beta^{n}-\alpha^{n}\right)}{3(\alpha \beta)^{n}}=\frac{(-1)\left(\alpha^{n}-\beta^{n}\right)}{3(-2)^{n}}= \\
=\frac{(-1)}{(-2)^{n}} \cdot \frac{\left(\alpha^{n}-\beta^{n}\right)}{3}=\frac{(-1)}{(-1)^{n} \cdot(2)^{n}} \cdot \frac{\left((2)^{n}-(-1)^{n}\right)}{3}=\frac{(-1)^{n+1}}{(2)^{n}} \cdot J_{n} .
\end{gathered}
$$

In the end, the student should note that the tests performed for some values of $n$, result in the Jacobsthal sequence as a way of extension to the integer indices.

\section{Institutionalization situation -}

In the last stage it is expected that the learner or group of learners adopt the meaning of knowledge that has been prepared by himself over the previous phases. In this way, the teacher returns to the discussions made in the previous steps, showing the possibility of obtaining Binet's formula, also in the field of integers.

The teacher may also point out the relationship

$$
J_{-n} \neq-J_{n}
$$

\section{Some Final Thoughts}

From this study the relevant elements to highlight are:

- The necessary bibliographic review in relation to knowledge (epistemological dimension). The search for the origins of mathematical knowledge allows the teacher to improve the relationship with knowledge, which increases the criticism in relation to the available teaching materials and can encourage work in the classroom.

- The mastery of methodological aspects can allow a creative and autonomous routine for the student, something less used in the teaching of Mathematics.

- The use of Didactic Engineering in association with the Didactic Situations Theory allowed us to organize the research in stages consistent with defined objectives.

- When carrying out the stage of preliminary analyzes, we constructed the theoretical framework of the mathematical objects of study, the Fibonacci sequence and Jacobsthal sequence. This step allowed us to identify and describe other generalization properties of each sequence, thus characterizing the achievement of the objectives related to analyzing the historical-mathematical-epistemological development of generalization of the sequences.

- From the theoretical basis of these sequences, carried out in the stage of preliminary analysis stage, we 
obtained the necessary theoretical support to be used in the design and a priorianalysis stage, stages in which we structured the entire action plan and the "Didactic situations" to be applied in experimentation. In this sense, we were able to describe "Didactic situations" involving the generalization model of each sequence.

- It should be noted that the stages presented are essential to the organization of the following stages of experimentation and a posteriori analysis and validation.

We finish hoping that the methodological path followed in these stages will be a reference for the organization of other investigations, based on the guidelines of Didactic Engineering in concurrence with the Didactic Situations Theory.

In a future publication, we will present new examples of application of Didactic Engineering (in its various versions) to studies of the most varied sequences (of quaternions, octonions, hybrid numbers, etc.).

Acknowledgment: The author is member of the Research Centre CMAT-UTAD as well as a collaborating member of the Research Centre CIDTFF. This research was partially financed by Portuguese Funds through FCT-Fundação para a Ciência e a Tecnologia, within the following Projects UIDB/00013/2020 and UIDB/00194/2020.

\section{References}

Almouloud, S. A. (2007). Fundamentos da Didática da Matemática [Fundamentals of Didactics of Mathematics]. Paraná: UFPR.

Almouloud, S. A., \& Silva, M. J. F. (2012). Engenharia Didática: Evolução e Diversidade [Didactic Engineering: Evolution and Diversity]. Revemat - R. Eletr. de Edu. Matem., Florianópolis, $7(2), 22-52$.

Alves, F. R. V. (2015). Sobre a evolução histórica do modelo de Fibonacci: a classe das funções hiperbólicas de Fibonacci [On the historical evolution of the Fibonacci model: the class of Fibonacci hyperbolic functions]. VYDIA Educação, 35(1), 133-146.

Alves, F. R. V. (2016). Didática da Matemática: seus pressupostos de ordem epistemológica, metodológica e cognitive [Didactics of Mathematics: its epistemological, methodological and cognitive assumptions]. Interfaces da Educação, Paranaíba, 7(21), 131-150.

Alves, F. R. V. (2016a). Engenharia Didática para a generalização da Sequência de Fibonacci na disciplina de História da Matemática: uma experiência num curso de licenciatura [Didactic Engineering for the generalization of the Fibonacci Sequence in the discipline of History of Mathematics: an experience in a degree course]. Educação Matemática Pesquisa, 18(1), 61-93.
Alves, F. R. V. (2016b). Descobrindo definições matemáticas no contexto de investigação histórica: o caso da Sequência Generalizada de Fibonacci [Discovering mathematical definitions in the context of historical research: the case of the Generalized Fibonacci Sequence]. Boletim GEPEM, 68, 112-117.

Alves, F. R. V. (2016c). Sequência Generalizada de Pell - SGP: aspectos históricos e epistemológicos sobre a evolução de um modelo [Generalized Pell Sequence - SGP: historical and epistemological aspects about the evolution of a model]. Revista THEMA, 13(2), 27-41.

Alves, F. R. V. (2017). Engenharia Didática para a s-Sequência Generalizada de Jacobsthal e a $(s, t)$ - Sequência Generalizada de Jacobsthal: análises preliminares e $a$ priori [Didactic Engineering for the Generalized Jacobsthal s-Sequence and the $(\mathrm{s}, \mathrm{t})$ - Generalized Jacobsthal Sequence: preliminary and a priori analyzes]. Revista Iberoamericana de Educación Matemática, 51, 83-106.

Alves, F. R. V. (2018). Engenharia Didática de Formação (EDF): sobre o ensino dos Números (Generalizados) de Catalan (NGC) [Didactic Training Engineering (DTF): on teaching Catalan (Generalized) Numbers (CGN)]. Educação Matemática Pesquisa, São Paulo, 20(2), 47-83.

Alves, F. R. V., \& Alves Dias M. (2017). Formação de Professores de Matemática: um contributo da Engenharia Didática [Mathematics Teacher Training: a contribution from Didactic Engineering]. Revemat, Florianópolis, (SC), 12(2), 192-209.

Alves, F. R. V., \& Catarino, P. M. C. (2017). Engenharia Didática de Formação (EDF): repercussões para a formação de professores de Matemática no Brasil [Didactic Engineering of Training (DET): repercussions for the formation of Mathematics teachers in Brazil]. Educação Matemática em Revista - RS, 2(18), 121-137.

Alves, F. R. V., \& Catarino, P. M. C. (2018). Engenharia Didática de 2. a geração com o tema: $h(x)$ - polinômios de Jacobsthal [2nd generation Didactic Engineering with the theme: $\mathrm{h}(\mathrm{x})$ Jacobsthal polynomials]. Ensino de Ciências e Tecnologia em Revista, 8(3), 28-55.

Alves, F. R. V., \& Catarino, P. M. C. (2019). Situação Didática Profissional: um exemplo de aplicação da Didática Profissional para a pesquisa objetivando a atividade do professor de Matemática no Brasil [Professional Didactic Situation: an example of the application of Professional Didactics for research aiming at the activity of the Mathematics teacher in Brazil]. Indagatio Didactica, 11(1), 103-129.

Angel-Alvarado, R., Wilhelmi, M. R., \& Belletich, O. (2017). Designbased research for Music Education: Didactical engineering. In Proceedings of ECER 2017 - Reforming Education and the Imperative of Constant Change: Ambivalent roles of policy and educational research, (pp. 21-25) August at University College UCC, Copenhagen.

Artigue, M. (1988). Ingénierie didactique. Recherches en Didactique des Mathématiques, 9(3), 281-308.

Artigue, M. (1999). The teaching and learning of mathematics at the university level. Crucial questions for contemporary research in education. Notices of the AMS, 46(11), 1377-1385.

Artigue, M. (2000). Didactic engineering and the complexity of learning processes in classroom situations. In C. Bergsten, G. Dahland, \& B. Grevholm (Eds.), Proceedings of the MADIF 2 - the 2nd Swedish Mathematics Education Research Seminar, 
(pp. 5-20), January 26-27, Gothenburg: Swedish Society for Research in Mathematics Education.

Artigue, M. (2011). L'ingénierie didactique comme thème d'étude. In C. Margolinas, et al. (Eds.) (2011), En amont et en aval des ingénieries didactiques (pp. 15-25). Grenoble: La Pensée Sauvage Editions.

Artigue, M. (2011a). L'ingénierie didactique: un essai de synthèse. In C. Margolinas, et al. (Eds.) (2011), En amont et en aval des ingénieries didactiques (pp. 225-237). Grenoble: La Pensée Sauvage Editions.

Berenguer, M. I. S. (2010). A aplicação da Engenharia Didática no Ensino das Ciências Exatas [The application of Didactic Engineering in the Teaching of Exact Sciences]. Postgraduate thesis for obtaining the specialist degree in higher education teaching, University Cândido Mendes, Rio de Janeiro, Brazil.

Brousseau, G. (1986). Fondements et méthodes de la Didactiques des Mathématiques. Recherche en Didactiques des Mathématiques. 7(2), 33-115.

Brousseau, G. (1996). Fundamentos e Métodos da Didáctica da Matemática [Foundations and Methods of Didactics of Mathematics]. In Brun, J., Didática das Matemáticas [Didactics of Mathematics]. Translation by Maria José Figueiredo. Lisboa: Instituto Piaget, 1996. Chapter 1, pp. 35-113.

Brousseau, G. (1996a). Os diferentes papéis do professor [The different roles of the teacher]. In Parra, C. \& Saiz, I., Didática da Matemática: Reflexões Psicopedagógicas [Didactics of Mathematics: Psychopedagogical Reflections]. Translation by Juan Acuña Llorens. Porto Alegre: ArtMed, 1996. Chapter 4, p. 48-72.

Brousseau, G. (1997). Theory of didactical situations in mathematics. Dordrecht, The Netherlands: Kluwer.

Brousseau, G. (2008). Research in mathematics education. In M. Niss (Ed.), Proceedings of the 10th International Congress on Mathematical Education (pp. 244-254). IMFUFA: Denmark.

Brun, J. (2000). Didáctica das Matemáticas [Didactics of Mathematics]. Horizontes Pedagógicos, Instituto Piaget, 4th edition, Lisbon, Portugal.

Chevallard, Y. (1991). La transposition didactique (2nd ed.). Grenoble: La Pensée Sauvage Editions.

Chevallard, Y. (1992). Concepts fondamentaux de la didactique: Perspectives apportées par une perspective anthropologique. Recherches en Didactique des Mathematiques, 12(1), 73-112.

Civiero, P. A. G., \& Sant'Ana, M. de F. (2013). Roteiros de Aprendizagem a partir da Transposição Didática Reflexiva [Learning Paths from the Reflective Didactic Transposition]. Bolema, Rio Claro (SP), 27(46), 681-696.

Douady, R. (1995). La ingeniería didáctica y la evolución de su relación con el conocimiento. In Artigue, M., Douady, R., Moreno, L., \& Gómez, P. (Ed.), Ingenieria Didactica en Educación Matemática (pp. 61-96) Bogotá: Grupo Editorial Iberoamericano.

Godino, J. D., Batanero, C., Contreras, A., Estepa, A., Lacasta, E., \& Wilhelmi, M. R. (2013). Didactic Engineering as Design-Based Research in Mathematics Education. In Ubuz, B., Haser, C., \& Mariotti, M. A. (Eds.). (2013). Proceedings of the Eighth Congress of the European Society for Research in Mathematics Education pp. 2810 - 2819, (CERME 8, February 6-10, 2013). Ankara, Turkey: Middle East Technical University and ERME.

Godino, J. D., Rivas, H., Arteaga, P., Lasa, A., \& Wilhelmi, M. R. (2014). Ingeniería didáctica basada en el enfoque ontológicosemiótico del conocimiento y de la instrucción matemáticos. Recherches en Didactique des Mathématiques, 1-37.

González-Martín, A. S., Bloch, I., Durand-Guerrier, V., \& Maschietto, M. (2014). Didactic Situations and Didactical Engineering in university mathematics: cases from the study of Calculus and proof. Research in Mathematics Education, 16(2), 117-134, doi: 10.1080/14794802.2014.918347.

Guimarães, R. S., Barlette, V. E., \& Guadagnini, P. H. (2015). A engenharia didática da construção e validação de sequências de ensino: um panorama com foco no ensino de ciências. Polyphonia, 26(1), 211-226.

Lima, J. R., \& Ferreira, H. (2020). Contribuições da Engenharia Didática como elemento norteador no Ensino de Física: estudando o fenômeno de Encontro de Corpos com atividades da Robótica Educacional. Revista Brasileira de Ensino de Física, 42, e20190021 (2020), p. 12, doi: http://dx.doi. org/10.1590/1806-9126-RBEF-2019-0021.

Machado, S. D. A. (2002). Engenharia Didática. In Machado, S. D. A. (org.). Educação Matemática: Uma introdução, (pp. 197-208), 2nd edition, São Paulo: EDUC.

Margolinas, C., Abboud-Blanchard, M., Bueno-Ravel, L., Douek, N., Fluckiger, A., Gibel, P., et al. (Eds.). (2011). En amont et en aval des ingénieries didactiques. Grenoble: La Pensée Sauvage Editions.

Margolinas, C., \& Drijvers, P. (2015). Didactical engineering in France; an insider's and an outsider's view on its foundations, its practice, and its impact. ZDM Mathematics Education, 47(6), 893-903. https://doi.org/10.1007/s11858-015-0698-z.

Melzer, E. E. M. (2012). Do saber sábio ao saber a ensinar: $a$ transposição didática do conteúdo modelo atômico de livros de química (1931-2012) [From wise knowledge to knowing how to teach: the didactic transposition of the atomic model content of chemistry books (1931-2012)]. Master Thesis in Science Teaching - Exact Sciences Sector, Curitiba, Federal University of Paraná, Brazil.

Melzer, E. E. M., Simões Neto, J. E., \& Silva, F. C. V. (2016). Analisando as pesquisas envolvendo transposição didática de conteúdos químicos publicadas no Brasil [Analyzing research involving didactic transposition of chemical contents published in Brazil]. Ensino de Ciências e Tecnologias em Revista, 6(1), 100-114.

Menezes, E. T. de, \& Santos, T. H. dos. (2001). Verbete transposição didática. Dicionário Interativo da Educação Brasileira - Educabrasil. São Paulo: Midiamix, 2001. Retrieved from (08-02-2020): <https://www.educabrasil.com.br/transposicaodidatica/>

Oliveira, G. P., \& Pereira, A. C. C. (2018). 0 uso da Engenharia Didática como ferramenta facilitadora para utilização e produção de Objetos de Aprendizagem a partir da formação inicial e continuada de professores de Matemática [The use of Didactic Engineering as a facilitating tool for the use and production of Learning Objects from the initial and continuing training of Mathematics teachers]. Boletim Cearense de Educação e História da Matemática, 5(13), 48-65, doi: 10.30938/bocehm.v5i13.19.

Pastré, P., Mayen, P., \& Vergnaud, G. (2006). La didactique professionnelle. Revue Française de Pédagogie, 154, 145-198.

Pereira, R. C., Paiva, M. A. V., \& Freitas, R. C. de O. (2018). A transposição didática na perspectiva do saber e da formação 
do professor de matemática [Didactic transposition from the perspective of knowledge and the training of the mathematics teacher]. Educ. Matem. Pesq., São Paulo, 20(1), 41-60.

Perrin-Glorian, M. J. (2011). L'ingénierie didactique à l'interface de la recherche avec l'enseignement. Développement de ressources et formation des enseignants. In C. Margolinas, et al. (Eds.) (2011), En amont et en aval des ingenieries didactiques (pp. 57-74). Grenoble: La Pensée Sauvage Editions.

Perrin-Glorian, M. J., \& Bellemain, P. M. B. (2019). L'Ingénierie Didactique entre Recherche et Ressource pour L'Enseignement et la Formation des Maitres. Caminhos da Educação Matemática em Revista/Online, 9(1), 45-82.

Polidoro, L. de F., \& Stigar, R. (2010). A Transposição Didática: a passagem do saber científico para o saber escolar [Didactic Transposition: the transition from scientific knowledge to school knowledge]. Ciberteologia - Revista de Teologia \& Cultura - Ano VI, 27, 1-7.

Pomer, W. M. (2013). A Engenharia Didática em sala de aula: Elementos básicos e uma ilustração envolvendo as Equações Diofantinas Lineares [Didactic Engineering in the classroom: Basic elements and an illustration involving Diophantine Linear Equations], p. 72, ils.: Tabs. São Paulo, Brazil.

Santos, A. A. dos, \& Alves, F. R. V. (2017). A Engenharia Didática em articulação com a Teoria das Situações Didáticas como percurso metodológico ao estudo e ensino de Matemática [Didactic Engineering in conjunction with Didactic Situations Theory as a methodological path to the study and teaching of Mathematics]. Acta Scientiae, Canoas, 19(3), 447-465.

Souza, T. S. A. de, \& Alves, F. R. V. (2018). Engenharia Didática como instrumento metodológico no estudo e no ensino da sequência de Jacobsthal [Didactic Engineering as a methodological tool in the study and teaching of the Jacobsthal sequence]. \# Tear: Revista de Educação Ciência e Tecnologia, Canoas, 7(2), 1-19.

Tempier, F. (2016). New perspectives for didactical engineering: an example for the development of a resource for teaching decimal number system. J. Math. Teacher Educ., 19(2-3), 261-276, doi: 10.1007/s10857-015-9333-8.

Verret, M. (1975). Le Temps des Études. PhD Thesis. Paris, France. Retrieved from (11-02-2020): http://www.sudoc.fr/000031526

Warfield, V. (2006). Invitation to Didactique. Seattle: University of Washington. 